\title{
Evaluating Online Course Quality: A Study on Implementation of Course Quality Standards
}

\author{
Whitney Zimmerman \\ The Pennsylvania State University \\ Barbara Altman \\ Texas A\&M University - Central Texas \\ Bethany Simunich, Kay Shattuck, and Barbra Burch \\ Quality Matters
}

\begin{abstract}
This study examined the relationship of intentional faculty professional development, intentional online course design, and informal course reviews to the results of official interinstitutional peer review within higher education institutions. Quality Matters ${ }^{\text {мм }}(\mathrm{QM})$ provided the setting for this exploration of the relationship of three independent variables at the course level at institutions that have voluntarily implemented QM online learning quality assurance tools and processes. Data for this study were extracted from a larger statistical project conducted regularly by QM, which included the results of 5,436 online course reviews completed between September 2014 and May 2020 at 360 institutions. These courses were assessed for meeting quality standards in structured, interinstitutional, reviews, conducted by three faculty peer reviewers. QM provided the setting and data for this study; however, the study was not about QM. Instead, it was about exploring the relationships of variables within an institution's control in the quest for benchmarking and improving online learning. Having and disseminating online course quality standards does not ensure implementation of those standards and quality assurance processes. This observational study provides a better understanding of how the implementation of those standards and quality assurance processes might impact outcomes.
\end{abstract}

Keywords: course design, professional development, quality assurance, quality standards

Zimmerman, W., Altman, B., Simunich, B., Shattuck, K., \& Burch, B. (2020). Evaluating online course quality: A study on implementation of course quality standards. Online Learning, 24(4), 147-163. https://doi.org/10.24059/olj.v24i4.2325 


\section{Evaluating Online Course Quality: A Study on Implementation of Course Quality Standards}

Online learning is mainstreaming in U.S. higher education institutions (Garrett et al., 2020; Seaman et al., 2018); therefore, the impact of faculty practice, intentional online course design, and the relationship of institutionally supported quality processes are vital to explore. The COVID19 pandemic raises the urgency of providing quality online learning (Means, 2020). The assumption that faculty, who have discipline expertise, are necessarily trained and skilled in instructional design has been challenged (Kearns \& Mancilla, 2016). At the same time, it is recognized that online courses need specific attention to instructional design (Kamenetskiy, 2014; Kennedy, 2014; Moore, 2019). Faculty exposure to and application of course design standards, along with a review for course quality, are parts of an institution's quality assurance processes (Adair \& Shattuck, 2019).

While the team approach to developing and designing online courses is practiced in some U.S. higher education organizations (Garrett et al., 2020; Moore \& Kearsley, 2012), it is not the dominant approach. Faculty are often charged with designing online courses on their own, within or outside of the institution's quality assurance standards and processes (e.g., Baldwin, 2019). Some institutions have developed and implemented their own quality standards and faculty development for online course design, as well as internal processes to review online courses for quality. For example, the University of Central Florida (UCF) has a long history of implementing their own institutional best practices for online learning (O'Brien, 2015), and Chico State University established the Quality Learning and Teaching (QLT) instrument. However, many institutions choose to rely on online design quality standards created by online learning organizations, such as the Association of Educational Communications and Technology (AECT) Instructional Design Standards for Distance Learning, the Online Learning Consortium (OLC) Scorecard, the Open SUNY Center Course Quality Review Rubric (OLC OSCQR), and Quality Matters (QM) Rubrics ${ }^{\mathrm{TM}}$.

The purpose of this study was to examine the relationship of intentional professional development, intentional course design, and informal course review to results of official interinstitutional peer review within higher education institutions that voluntarily support and use validated course design standards. QM served as the setting for this study by providing autonomous, longitudinal data from official QM course reviews. QM is a not-for-profit educational quality assurance organization that has provided interinstitutional faculty peer review of online course design since 2005. These reviews and accompanying professional development are grounded in a set of validated online course design standards. These standards and peer review guidance are encapsulated in the official QM Rubric. Data for this observational study were extracted from a larger data set used in a statistical project that QM conducts regularly.

\section{Review of Relevant Literature}

This observational study is situated in the extensive literature on online quality assurance and informed by a review of online learning professional development and course design research.

\section{Professional Development}

Professional development in the form of training specifically for designing and teaching online is a broad topic in both the peer review and gray literature. Specific training focused on 
online design and teaching helps instructors empower online learners "to manage their own learning experience through time and energy management" (Sanga, 2018, p. 15). Mohr and Shelton (2017) used the Delphi study methodology to develop best practices for professional development for faculty teaching online. Gibbons et al. (2019) reviewed continuing professional education as a vehicle to address development of knowledge and skill for practitioners of online distance education, while Shattuck (2019) summarized it as "moving training into application and practice" (p. 428). The benefits of including a networking community of learning atmosphere in online learning training have been noted (Cowan et al., 2017; Hollowell et al., 2017; Richardson et al., 2020; Scarpena et al., 2018), as has been self-assessed to determine the level of readiness for training (Rhodes et al., 2017). Faculty exposure to and application of course design standards, along with a collaborative review for course quality have been shown to benefit faculty's perceptions of the impact of course design on online learning (Bogle et al., 2014; Geiger et al., 2014; Kearns, 2015). Further, faculty exposure to and application of course design standards, along with a collaborative review for course quality, are parts of an institution's quality assurance processes (Adair \& Shattuck, 2019; Brinkley-Etzkorn, 2019; Taylor et al., 2018), yet they continue to be filled with administrative-level implementation challenges (Garrett et al., 2020).

The impact of QM faculty training has been explored. For example, Christie and Skylar (2017) tracked and analyzed outcomes of more than 1,400 QM trainings over 23 campuses of the California State University System completed over a five-year period. Their study provided evidence for the importance of raising awareness, creating a culture of excellence, and shifting the focus from outputs to outcomes.

Gregory (2018), also examined the impact of QM-related professional development. She found that specific QM training had a positive influence on faculty perceptions of online course design. The importance of the larger quality assurance culture of an institution was noted:

...social influences and facilitating conditions within the local setting where faculty engage with distance education [need to be considered. Further,] higher education institutions may need to develop a comprehensive plan that addresses the many aspects of quality assurance, including, but not limited to, faculty professional development, course design support, and evaluation of online course delivery. (pp. 109-110)

\section{Course Design}

Course design is the instructional blueprint of an online course that is developed before a course is delivered - that is, before there are any active instructors and any learners involved in making it come alive with dynamic learning engagements. It is a course shell from which an instructor launches teaching and learning. Instructional design has been a well-established field that has forwarded in the past decades to instructional design practice (for example, see Bond \& Dirkin, 2018; Piña \& Harris, 2019). The instructional course design is the foundation, a blueprint, from which instructor and learner begin their learning engagement.

Improved online course design has been associated with improved student learning (Bogle et al., 2014; Harkness, 2014). The Community of Inquiry framework (CoI) (Garrison et al., 2000 ${ }^{1}$ ). provides a vehicle to view course design in relation to teaching facilitation and engaging learners. The framework includes the interrelated teaching presence, social presence, and cognitive presence. Simply put, presence can be understood as engagement—with other participants, with

\footnotetext{
${ }^{1}$ See also http://www.thecommunityofinquiry.org/coi and http://coi.athabascau.ca
} 
instructors, with materials and content - in a way that a learner feels personal agency. The rich topic of $\mathrm{CoI}$ is beyond the scope of this article except as it relates to the dimensions of teaching presence: "design, facilitation, and direction of cognitive and social processes for the purpose of realizing personally meaningful and educational worthwhile learning outcomes"' (para. 1) ${ }^{2}$.

Course design features, including authentic and relevant course materials, multimedia resources, activities for digital content to be collaboratively created by learners, opportunities for learners to reflect on their own learning, and "the instructor's explanation of the purpose of activities, technologies, and assessments in the online course," were identified by nationally celebrated online teachers as important (Kumar at al., 2019, para. 1). In describing instructional design from a transactional distance systems theory to practice, Shearer and Park (2019) connected course design factors, such as interaction and social presence, to the broader institutional-level factors of access and costs.

\section{Quality Assurance}

Creation and dissemination of best practices and standards for online/distance education has a decades-long history. Esfijani (2018) analyzed 112 publications written between 2000 and 2017 of measures of online quality education. Twenty-four different quality online education dimensions, standards, benchmarks, and guidelines were identified. Esfijani noted that pre-2002 publications focused on quality standards and indicators, with later publications providing more detailed standards as well as measurement strategies. There are varying degrees of transparency in development of standards and in continual validation. The International Board of Standards for Training, Performance and Instruction (ibstpi) is an example of standards that provide a transparent and rigorous system of reviewing and revising standards. According to their website, ibstpi "has a rigorous process primarily involved in research and development activities" to "develop, validate, publish, and disseminate" performance statements, including instructors, training managers, instructional designers, and evaluators" (para. 2). Shattuck et al. (2014) provided an overview of QM's transparent processes for continually validating course design standards and peer review processes.

Faculty active participation in quality assurance processes has been found to be a positive experience related to receptivity of feedback from internal quality assurance review (Bazluki et al., 2018; McNeal \& Gray, 2019). Yet, it has been recommended that administrators should review the pressures faculty might experience in "decision fatigue of the observed" (Taylor et al., 2018).

The availability of quality standards does not ensure appropriate application or measurement, thus the call for investigation of how standards and processes are implemented within an institution. To that end, Adair (Adair \& Shattuck, 2019) posits a series of phases on a Continuum of Excellence that higher education organizations traverse as they institutionalize quality online standards. The study reported here informs that type of research by making datasupported observations that can be connected to local institutional level practices (Shattuck et al., 2020). This study looks at faculty development, intentional course design, and informal course review as parts of an institution's quality assurance management. Specifically, this study investigates three factors that might influence successful attainment of benchmarking online quality standards at the course level.

\footnotetext{
${ }^{2}$ See https://coi.athabascau.ca/coi-model/description-teaching-presence
} 


\section{Theoretical Framework}

Implementation Science (IS) (McKay, 2015) using the Determinant Framework (ISDF) (Nilsen, 2015) serves as the theoretical framework. The determinants or factors studied in this research are: professional development, intentional course design, informal course reviews, and the relationship of these to benchmarking interinstitutional peer assessment of an online course as meeting quality design standards. This study is informed also by a design-based implementation research (DBIR) approach that considers the characteristics of the intervention, the implementation strategies, and the outcomes (Fishman et al., 2013) $)^{3}$.

\section{Study Setting: Quality Matters}

QM was established by a small group of educators in 2003 with a Fund for the Improvement of Postsecondary Education (FIPSE) grant from the U.S. Department of Education. The charge in the grant was to create a replicable, scalable process for course quality assurance. After funding ended in 2006, QM became a self-supporting, not-for-profit organization.

QM is the provider of online learning professional development and has trained over 52,000 faculty and staff. More than 1,300 member institutions in all 50 states and 20 countries participate in some level of adoption and adaptation of the QM Standards, professional development, and course review processes to assist with their own quality assurance for online learning.

\section{About the QM Higher Education Rubric}

The QM Rubric reflects online learning research and best practices and is regularly updated and revised by an external committee of faculty, researchers, instructional designers, and other online learning experts (See Shattuck, Zimmerman, \& Adair, 2014). Since the first QM Rubric, nearly 100 faculty and online learning experts have contributed to the rubric revisions. Additionally, over a dozen graduate students and QM Research Colleagues have assisted in creating the literature reviews that inform the work of the experts revising the rubric, who also receive the aggregated responses of hundreds of survey feedback responses from faculty who use the QM Rubric in their work.

The Sixth Edition of the QM Higher Education (QM HE) Rubric is organized by eight general standards: (1) Course Overview and Introduction, (2) Learning Objectives, (3) Assessment and Measurement, (4) Instructional Materials, (5) Learning Activities and Learner Interaction, (6) Course Technology, (7) Learner Support, and (8) Accessibility and Usability. Organized under the eight General Standards, also, are 42 specific review standards (SRS). Each standard on the QM HE Rubric has an assigned value of 3 points (essential), 2 points (very important), or 1 point (important). However, the standards are not the rubric, as each standard must be considered in conjunction with the assigned annotation, which provides examples and detailed guidance for faculty peer reviewers.

\section{The QM Course Review Process}

QM provides a detailed official review process for online course quality. A QM Official Review is conducted by a team of three, trained faculty Peer Reviewers (QM PR). The team of three must include one reviewer who is a subject matter expert in the academic area of the course to be reviewed and at least one reviewer who is external to the course home institution. The review

\footnotetext{
3 See also http://learndbir.org.
} 
team includes and is led by a Master Reviewer who has received additional training and has experience conducting QM reviews. Only a structured peer review using the full QM HE Rubric can be labelled as an official QM review.

The Course Representative (CR) is the faculty member who is representing the course; most often, this individual is the one who has designed and/or taught the course. The course representative completes an informational course worksheet prior to the start of the review. The Course Worksheet (CW) includes questions about the course, such as whether the learning objectives are institutionally mandated, how the instructor plans to interact with students, and if there are areas in the course for which the instructor would like specific feedback. The CW asks if the course developer/designer has taken professional development in online course design, if they designed their course to meet quality standards, and if the course has already been internally reviewed by their institution using internal, institutional quality standards - three questions which provided the data for this study. The CR is considered a member of the review team and provides information or "quick fixes" as needed during the review but does not actively review their own course.

For each standard, each individual PR evaluates whether the standard was met or not met at the $85 \%$ level. This assessment is based on the peer reviewer's determination of whether or not evidence was observed within the design of the course to meet the standard at an $85 \%$ threshold. Overall, in order for a standard to be met, at least two of the three reviewers must agree. The final review score is based on accumulated points for each standard, and the maximum possible score is 100 points. A course is certified as meeting QM Standards if it scores at least 85\% of the maximum total possible, which must include meeting all 3-point (i.e., essential) standards. If a course does not meet standards in the initial review, it may be revised and re-reviewed. The approximately 50\% of courses that do not meet QM standards upon initial review take the 14 weeks in the review Amendment Phase to make faculty-driven revisions, which are then reviewed by the Master Reviewer.

The review lasts approximately three weeks and begins with a review team conference call, which is attended by the three peer reviewers and the course representative. All three PRs evaluate the course design independently, providing constructive, helpful recommendations along the way. The active review period ends with a reviewer conference call to discuss findings and feedback.

This study uses data collected as part of the QM official review process, exploring the relationship of: (a) completion of institutional-level professional development by the faculty course developer on online course design standards, (b) application of quality standards during the course design phase, and (c) participation in internal course reviews on the outcome of the official interinstitutional peer review of a course.

\section{Course Review Outcomes Analyses}

A statistical analysis of QM's internal data has been conducted for QM by an independent statistician in 2010, 2013, and 2016. These reports were ordered to inform the work of the committee assigned to review the QM Rubric in preparation for suggesting revisions for an updated version of it. This study included data from the 2016 report, which covered official reviews from 2014 to 2016 and from corresponding data pulled from QM data on reviews completed from 2016 to May 2020. 


\section{Research Questions}

The purpose of this study was to examine the relationship between implementation of three institutional quality assurance processes and outcomes of official QM interinstitutional peer reviews of the design quality of online courses.

The following research questions were addressed:

R1. Do course developers who have experienced professional development in the application of QM standards tend to have more favorable outcomes in an official QM interinstitutional peer review compared to course developers who have not experienced QM-related professional development?

R2. Do courses designed to meet QM standards tend to have more favorable outcomes in an official QM interinstitutional peer review compared to courses not designed to specifically meet QM standards?

R3. Do courses that are pre-reviewed at the institutional level tend to have more favorable outcomes in an official QM interinstitutional peer review compared to courses that are not pre-reviewed?

\section{Methods}

Data were drawn from QM's Course Review Management System (CRMS) digital tool, which is used to gather and analyze data collected during official QM course reviews. Data is entered into the CRMS by the various individuals with roles in the course review process; the course representative completes an informational course worksheet to situate the peer reviewers to do their review; the peer reviewers enter their met or not met determinations for each specific review standard along with their recommendations for improvement; the master reviewer aggregates the recommendations into a final report. The result of the course review is shared with the course representative along with the course improvement recommendations.

This study includes the results of 5,436 QM reviews completed between September 2014 and May 2020. These courses were submitted for an official QM interinstitutional peer review from 360 institutions. The reviews were conducted by teams of QM PRs that consisted of 6,308 faculty reviewers and 360 course representatives. All identifying information about the institution, the peer reviewers, and the course (other than academic discipline) was stripped from the data files that were provided to the independent statistician for analyses.

Table 1

Institution Types for the 360 Participating Institutions

\begin{tabular}{lll} 
& Number & Percent \\
\hline Two-Year & 130 & $36 \%$ \\
Four-Year & 226 & $63 \%$ \\
Other & 4 & $1 \%$ \\
Total & 360 & $100 \%$ \\
\hline
\end{tabular}


All reviews were completed using QM's Higher Education Rubric. This includes 3,941 reviews using the QM Higher Education Rubric, Fifth Edition, and 1,495 reviews using the QM Higher Education Rubric, Sixth Edition. The difference between the two editions is primarily the reordering of some standards and the change of point value for a few standards ${ }^{4}$. These changes did not impact the final outcome of a course review nor the three questions that faculty course representatives responded to on the course worksheet.

Data concerning the course and course developer were collected from course worksheets. The worksheet included questions concerning whether the course was originally designed, or redesigned, to meet QM standards; whether the course developer had completed any QM-related professional development; and whether the course had been informally reviewed at the institutional level prior to submission for an official QM peer review. Data for this study were pulled from a larger statistical analysis of official QM peer reviews, and data from initial course reviews were correlated with responses to three of the questions on the course worksheet.

\section{Results}

The data pulled from QM's CRMS were used to address each of the three research questions. For each research question, two dependent variables were examined: (a) the scores on the initial review, and (b) whether or not the course was certified as meeting QM standards following the initial review. In order to meet standards, the course must have achieved a total score of at least $85 \%$ of the total possible number of points and must have met all of the 3-point (i.e., "essential") standards.

\section{R1: Do course developers who have completed professional development in the application of QM standards tend to have more favorable course review outcomes compared to course developers who have not experienced QM-related professional development?}

On the course worksheet, the course developer was asked if they had completed any professional development related to QM standards. This was measured dichotomously (yes/no). In the sample, 5,016 (92.3\%) of the course developers had completed some professional development related to QM standards, and 420 (7.7\%) of courses' developers had not.

Total scores on the initial reviews of courses with and without developers who had completed some professional development related to QM standards were compared. Scores were higher for courses with developers who had completed related professional development $(\mathrm{M}=$ 91.207, $\mathrm{SD}=9.443$ ) compared to courses whose developers had not completed related professional development $(\mathrm{M}=80.612, \mathrm{SD}=15.096)$. The difference between these two means was statistically significant $($ Welch $\mathrm{t}[446.87]=14.154, \mathrm{p}<.001)$ with a very large effect size $($ Cohen's $\mathrm{d}=1.060)$.

Courses with and without developers who had completed QM-related professional development were also compared in terms of whether they met standards in their initial review. Of the 5,016 courses whose developers had completed QM-related professional development, 2,707 $(54.0 \%)$ met standards in their initial review, and 2,309 $(46.0 \%)$ did not meet standards in their initial review. Of the 420 courses whose developers had not completed QM-related professional development, 106 (25.2\%) met standards in their initial review, and 314 (74.8\%) did not meet

\footnotetext{
${ }^{4}$ While the Fifth edition of the QM HE Rubric included a possible 99 points to meet standards and the Sixth edition of the QM HE includes a possible 100 points, final determination of meeting standards for both rubric versions required $85 \%$ of the standards being met, including all essential standards.
} 
standards in their initial review. The difference in proportions was statistically significant $(\mathrm{z}=$ $11.32, \mathrm{p}<.001)$. Courses with developers who had completed related professional development were more than twice as likely to meet standards in their initial review (relative risk $=2.143$ ).

\section{R2: Do courses designed to meet QM standards tend to have more favorable course review outcomes compared to courses not designed to specifically meet QM standards?}

The course worksheet that was completed when a course was submitted for an official QM review contained a question concerning whether or not the course was designed, or redesigned, to meet QM standards. This was measured dichotomously (yes/no). In the sample, 3,949 (72.6\%) of courses were designed to meet QM standards, and 1,487 (27.4\%) were not designed to meet QM standards.

Total scores on the initial reviews of courses that were and were not designed to QM standards were compared. Courses that were designed to meet QM standards had higher initial scores $(\mathrm{M}=91.739, \mathrm{SD}=9.065)$ compared to courses that were not designed to meet $\mathrm{QM}$ standards $(\mathrm{M}=86.802, \mathrm{SD}=12.587)$. This difference was statistically significant (Welch $\mathrm{t}[2093]$ $=13.835, \mathrm{p}<.001)$ with a medium effect size (Cohen's $\mathrm{d}=0.486)$.

Courses that were and were not designed to meet QM standards were also compared on the basis of whether or not they met standards in their initial review. Of the 3,949 courses designed specifically to meet QM course design standards, 2,222 (56.3\%) met standards in the initial review. Of the 1,487 courses not designed specifically to meet QM course design standards, 591 (39.7\%) met standards in the initial review. The difference between these two proportions was statistically significant $(\mathrm{z}=10.87, \mathrm{p}<.001)$. Courses that were designed to meet QM standards were 1.416 times more likely to meet standards in their initial review than courses that were not designed to meet QM standards.

\section{R3: Do courses that are pre-reviewed at the institutional level tend to have more favorable course review outcomes compared to courses that are not pre-reviewed?}

On the course worksheet, the course developer was asked whether or not the course had been informally pre-reviewed within their institution. This was measured dichotomously (yes/no). In the sample, 4,204 (77.3\%) of courses had been pre-reviewed, and 1,232 (22.7\%) of courses had not been pre-reviewed.

Total scores on the initial reviews were compared for courses that had and had not been pre-reviewed. Scores were higher for the courses that had been pre-reviewed $(\mathrm{M}=91.519, \mathrm{SD}=$ $8.943)$ compared to those that had not been pre-reviewed $(\mathrm{M}=86.532, \mathrm{SD}=13.560)$. The difference between these two means was statistically significant (Welch $\mathrm{t}[1557.4]=12.157, \mathrm{p}<$ $.001)$ with a medium effect size (Cohen's $d=0.490)$.

Courses that had and had not been pre-reviewed were also compared on the basis of whether or not they met standards in their initial review. Of the 4,204 courses that had been prereviewed, 2,303 (54.8\%) met standards on their initial review, and 1,901 (45.2\%) did not meet standards on their initial review. Of the 1,232 courses that had not been pre-reviewed, $510(41.4 \%)$ met standards on their initial review, and $722(58.6 \%)$ did not meet standards on their initial review. The difference in proportions was statistically significant $(z=8.27, p<.001)$. Courses that had been pre-reviewed were 1.323 times more likely to meet standards in their initial review compared to courses that had not been pre-reviewed. 


\section{Discussion}

Best practices and standards for online learning are promoted and discussed frequently in higher education. This study was an initial attempt to establish measures of quality tools and processes used by institutions towards continuous improvement and benchmarking of the quality of online courses. A large data bank was used to explore the relationship of faculty's participation in target training, use of quality standards in the development of an online course, and use of an internal review of the course on the outcome of an official peer review of the course. While QM provided the data for this study, its significance lies in its focus on a measurable outcome of an institution's implementation of selected quality assurance tools and processes. In this study, the outcome is interinstitutional peer review of course quality, which is achieved by a course meeting QM quality standards during an official peer review. The outcome of the peer review provides the institution a benchmark of its quality. While the results of this study using QM data cannot be generalized (see Limitations section), some possibilities are discussed.

With the results in hand, we were reminded of Goodyear's (2015) construct of actionable knowledge. Goodyear explained actionable knowledge as:

The knowledge needed to design, in education as in other fields, is actionable knowledge: that is, knowledge that is sufficient to inform action in the world. Unlike (educational) researchers, who can remain perpetually equivocal about the status and sufficiency of what is known through research, teachers and designers must make decisions, usually on the basis of fragmentary, heterogeneous and uncertain knowledge. Their work practices are framed by unmissable deadlines - courses, materials, assessment tasks, rooms, etc. have to be ready by a fixed date. They have a moral obligation to act, in the best interests of their students. (p. 38)

This assisted in our understanding of intentional training, design, and course review as proxies for continuous improvement interventions used by institutions. The model below represents our conceptual thinking about what we have found.

The three activities - intentional faculty training, intentional course design, and internal course review-could be considered a continuous improvement model to lead to a successful external benchmarking course review; however, this study did not extend to investigating the relative magnitude of each piece or even whether all three activities were critical. There was no attempt in this study to gather other data that has been noted in the literature to impact online learning, such as instructor engagement/teaching of a course, student readiness, or institutional support in place. 
Figure 1. Three institutional level activities that have a relationship to external course benchmarking in this study.

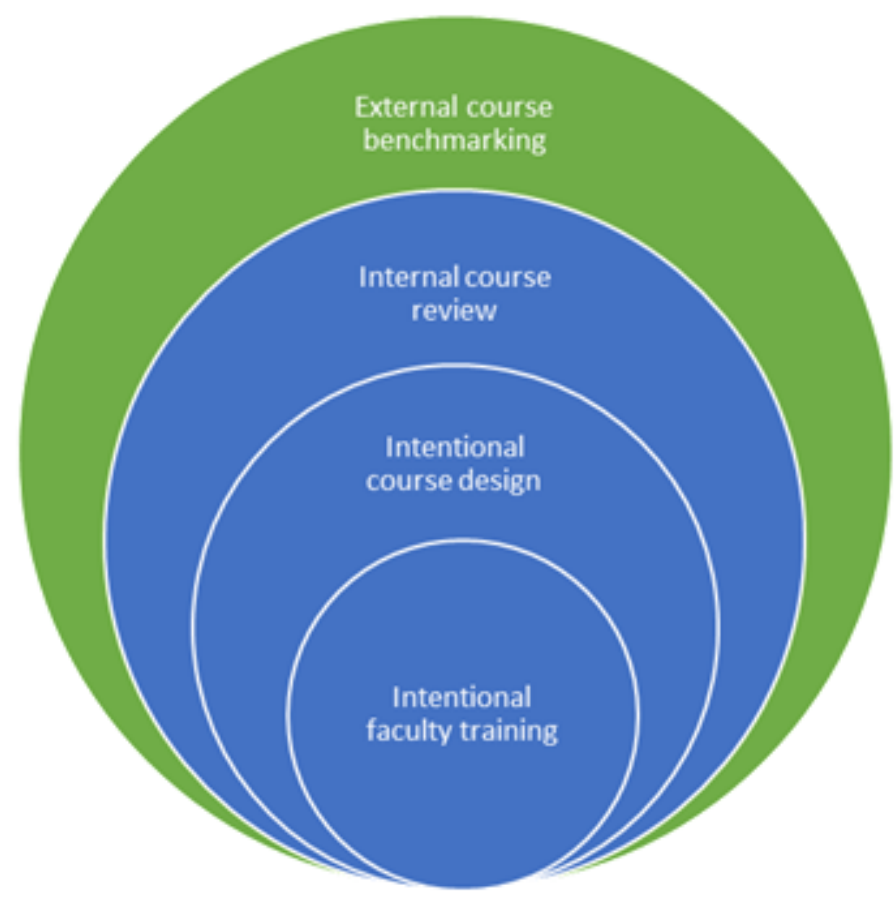

Quality assurance in higher education is a concept model (Ryan, 2015) that provides consistent assessment of learning design, content, and pedagogy (Puzziferro \& Shelton, 2008, as cited in Ryan, 2015). Online courses are developed, designed, and taught within that sometimesnebulous framework. Additionally, using the DBIR lens assisted in framing the results of this study within a quality assurance implementation framework. With that lens, we observed characteristics of the intervention, the implementation strategies, and the outcomes (Fishman et al., 2013). The result of the official course review was the outcome to which the input interventions of intentional faculty professional development workshops, intentional course design, and internal course review strategies were explored in relation to the peer review assessment of the course. In this study, there was no attempt to gather data about the institution's quality assurance system. The existence of intentional faculty professional development, intentional course design, and application of an internal quality review of a course served as three proxy features of the institution's supportive quality assurance practices. However, these are not the only ways that an institution could implement quality assurance practices for online course design.

For example, a single online course was the unit of analysis in this study and represented an entry point for possible future connections to other large-scale quality assurance measures within an institution. Further, exploring online quality standards at the course design level can be viewed as a bridge to gaining information on the impact and relationship of those standards and quality assurance processes to other aspects of online learning, such as satisfaction measures or learning performance or achievement. The online course, in essence, can serve as an institutional entry point for gathering data to better understand the impact and results of quality assurance measures for improving online learning. 
Online learning has been recognized for the flexibility of anytime, anywhere learning. Students have a large number of options from where they can pursue their educational goals. The realities of the COVID-19 pandemic make institutionally implemented quality assurance systems for online education even more crucial. Therefore, it is increasingly important for higher education institutions to evaluate, verify, and communicate their online quality to prospective students.

\section{Limitations and Future Research}

When discussing the findings of this study, it is also important to discuss its limitations. In this study, we examined the impact of an institution providing faculty training on understanding of - and faculty implementation of - quality design standards, as well as informal review of purposefully designed online courses. Two limitations related to the design of this study are lack of generalizability and inability to make causal conclusions. Because data were collected from a non-random sample, the results of this study should not be generalized. However, the sample was representative of the courses submitted for official QM reviews, so conclusions may be made in terms of that specific subset of courses. It is important to note that all courses included in this analysis were voluntarily put forth for official QM reviews. Additionally, because this was an observational study, causal conclusions cannot be made. For example, we can say that courses tended to have more positive outcomes when the course developer had relevant professional development experiences, but it cannot be concluded that professional development causes more positive course review outcomes.

Our data show that faculty who engaged in professional development related to online course design quality designed courses that met quality standards at a higher rate than faculty who did not engage in professional development. However, although it could be determined that all faculty course developers did complete the same professional development workshop on applying quality standards to the design of an online or hybrid course, the data did not include information on other professional development that the faculty may have taken. Future research should examine the data to see if there are certain workshops/workshop topics that have a greater positive impact on course design review outcomes than others.

Our data showed that faculty designing courses to meet quality standards do, in fact, meet these standards in an external quality review at a higher rate than faculty who did not design their courses to meet the quality standards. However, we did not collect data on whether the faculty developed the courses in isolation or if they had assistance, for example, from an institutional instructional designer. Collaboration with an instructional designer could, perhaps, produce higher-quality courses, so the potential impact of working with an instructional designer is unknown. Future research would do well to examine this relationship.

We found that courses that underwent an internal, institutional quality review prior to undergoing an official, external quality review met quality standards at a higher rate than courses that were not first institutionally reviewed. The data could not answer, though, whether the internal, institutional review used the exact same quality standards as did the external official review that was conducted through QM. Future research might more closely examine the relationship between institutional and external quality standards to more deeply examine the relationship between the two. QM is one of a number of education-based groups offering quality standards, faculty training, and reviews. Analyses of interinstitutional data collected by other organizations might reveal different relationships. 
Finally, the conceptual model presented in the discussion section that shows a continuous improvement model with the action items in this study needs further exploration. We do not know whether other elements are critical to a successful outcome of external quality review, nor do we know if all three of these elements are necessary.

\section{Conclusion}

With the steady growth of online learning, institutions will continue to seek ways to create and verify the quality of their online course and program offerings. Online learning has been recognized for the flexibility of anytime, anywhere learning. However, students may have a large number of options for how and where they can pursue their educational goals. The realities of the COVID-19 pandemic make institutionally implemented quality assurance systems for online education even more crucial, as students deserve quality online learning experiences, as well as institutions that have processes and resources in place to support them. Therefore, it is increasingly important for higher education institutions to evaluate, verify, and communicate their online quality to prospective students. One clear way to do this is by building in targeted online design and teaching training, establishing course development and design protocols, and conducting course quality assessments that can be benchmarked against validated interinstitutional standards of quality. This study used existing autonomous data from official QM peer reviews to examine impactful factors for courses that underwent interinstitutional peer reviews. Institutions would be well-advised to begin or continue a focus on faculty professional development for online course design, to communicate quality standards to faculty, to help faculty design courses to meet institutionally adopted standards, and to use internal reviews as part of their online quality assurance strategy. 


\section{References}

Adair, D. (2014). A process to improve course design: A key variable in course quality. In K. Shattuck (Ed.), Assuring quality in online education: Practices and processes at teaching, resource, and program levels (pp. 81-90). Stylus.

Adair, D., Shattuck, K., Burch, B., \& Zimmerman, W. A. (2019, November). 15 years of data on improving online learning design. [Conference presentation]. ICDE World Conference on Online Learning, Dublin, Ireland.

Adair, D., \& Shattuck, K. (2019). Ensuring quality while creating and innovating. In K. E. Linder (Ed.), The business of innovating online: Practical tips and advice from industry leaders (pp. 97-112). Stylus.

Baldwin, S. (2019). Assimilation in online course design. The American Journal of Distance Education, 33(3), 195-211. https://doi.org/10.1080/08923647.2019.1610304

Bazluki, M., Gyabak, K., \& Uderman, B. (2018). Instructor feedback on a formal online course quality assurance review process. Online Journal of Distance Learning Administration, 21(2). https://www.westga.edu/ distance/ojdla/summer212/bazluki_gyabak_udermann212.html

Bogle, L., Day, S., Matthews, D., \& Swan, K. (2014). The power of collaborative, collegial approach to improving online teaching and learning. In K. Shattuck (Ed.), Assuring quality in online learning (pp. 110-123). Stylus.

Bond, J., \& Dirkin, K. (2018). Instructional design: Study of a widening scope of practice. Online Journal of Distance Learning Administration, 21(4). https://www.westga.edu/ distance/ojdla/winter214/bond_dirkin214.html

Brinkley-Etzkorn, K. E. (2019). The effects of training on instructor beliefs about and attitudes toward online teaching. The American Journal of Distance Education, 34(1), 19-35. https://doi.org/10.1080/08923647.2020.1692553

Christie, B., \& Skylar, A. (2017, September 26). QM statewide systems talk data: Inputs, outputs, and outcomes [Conference presentation]. QM Connect Conference, Fort Worth, TX, United States. https://www.qualitymatters.org/qa-resources/resourcecenter/conference-presentations/qm-statewide-systems-talk-data-inputs-outputs

Cowan, J., Richter, S., Miller, T., Rhode, J., Click, A., \& Underwood, J. (2017). Building a sustainable Quality Matters ${ }^{\mathrm{TM}}$ community of practice through social network analysis. American Journal of Distance Education, 31(3), 160-172. doi:10.1080/08923647.2017.1316154

Fishman, B. J., Penuel, W. R., Allen, A.-R., Cheng, B. H., \& Sabelli, N. (2013). Design-based implementation research: An emerging model for transforming the relationship of research and practice. In B. J. Fishman \& W. R. Penuel (Eds.), National Society for the study of education: Vol 112 (pp. 136-156). http://isls-naples.psy.lmu.de/videoresources/guided-tour/15-minutes-penuel/fishman_penuel.pdf

Esfijani, A. (2018). Measuring quality in online education: A meta-synthesis. American Journal of Distance Education, 32(1), 57-73. https://doi.org/10.1080/08923647.2018.1417658 
Garrett, R., Legon, R., Fredericksen, E. E., \& Simunich, B. (2020). CHLOE 5: The pivot to remote teaching in spring 2020 and its impact, the changing landscape of online education, 2020. Quality Matters. https://www.qualitymatters.org/qa-resources/resourcecenter/articles-resources/CHLOE-5-report-2020

Garrison, D. R., Anderson, T., \& Archer, W. (2000). Critical inquiry in a text-based environment: Computer conferencing in higher education model. The Internet and Higher Education, 2(2-3), 87-105.

Geiger, L., Morris, D., Subocz, S. L., Shattuck, K., Viterito, A. (2014). Effect of student readiness on student success in online courses. Internet Learning, 3(1), 73-83. https://joom.ag/w08b/p72

Gibbons, S., Yauk, M., \& See, K. K. (2019). Trends and directions in continuing professional education, In M. G. Moore \& W. C. Diehl (Eds.), Handbook of distance education (4th ed., pp. 456-472). Routledge Press. https://doi.org/10.4324/9781315296135

Goodyear, P. (2015). Teaching as design. Herdsa Review of Higher Education, 2(2), 27-50. https://www.academia.edu/32521987/Teaching_as_design?email_work_card=view-paper

Gregory, R. L. (2018). Influence of Quality Matters ${ }^{\mathrm{TM}}$ professional development on faculty members' perceptions of design standards and their course development abilities. [Doctoral dissertation, The University of Memphis]. https://www.proquest.com/docview/2049753884

Harkness, S. S. J. (2014). Program administration and implementation of an online learning initiative at a Historically Black College University: A case study [Webinar]. EDUCAUSE/Quality Matters Online and Blended Learning: Institutional Case Studies on Implementing a Quality Assurance Program and Designing Research on Effective Practice Webinar Series. http://www.educause.edu/sites/default/files/library/presentations/ELI143/OL01/Harkness Online \%2BLearning\%2BInitiative.pdf

Hollowell, G. P., Brooks, R. M., \& Anderson, Y. B. (2017). Course design, quality matters training, and student outcomes. American Journal of Distance Education, 31(3), 207216. https://doi.org/10.1080/08923647.2017.1301144

International Board of Standards for Training, Performance and Instruction. (n.d.). About us. http://ibstpi.org/about-us/

Kamenetskiy, M. (2015). Evaluating faculty perceptions of teaching practices in online asynchronous courses: An action research study. (Publication No. 3719498) [Doctoral dissertation, Capella University]. ProQuest Dissertations and Theses Global.

Kennedy, A. (2015). Faculty perceptions of the usefulness of and participation in professional development for online teaching: An analysis of faculty development and online teaching satisfaction. (Publication No.3722998) [Doctoral dissertation, University of Wyoming]. ProQuest Dissertations and Theses Global.

Kearns, L. R. (2015). The experience of teaching online: Its impact on faculty professional development and innovation. [Doctoral dissertation, The Pennsylvania State University] Penn State Libraries. https://etda.libraries.psu.edu/files/final_submissions/10474 
Kearns, L. R., \& Mancilla, R. (2016). The impact of Quality Matters professional development on teaching across delivery formats. Quality Matters.

https://www.qualitymatters.org/sites/default/files/research-docs-pdfs/Impact-ofQM\%20Professional-Development-on-Teaching-across-Delivery-Formats.pdf

Kumar, S., Martin, F., Budhrani, K., \& Ritzhaupt, A. (2019). Award-winning faculty online teaching practices: Elements of award-winning courses. Online Learning, 23(4), 160180. doi:10.24059/olj.v23i4.2077

McKay, S. (2017, March 15). Quality improvement approaches: Implementation science. Carnegie Foundation for the Advancement of Teaching. https://www.carnegiefoundation.org/blog/quality-improvement-approachesimplementation-science/

Means, B., et al. (2020). Suddenly online: A national survey of undergraduates during the COVID-19 pandemic. Digital Promise.

Mohr, S. C., \& Shelton, K. (2017). Best practices framework for online faculty professional development: A Delphi study. Online Learning Journal, 21(4), 123-140. https://olj.onlinelearningconsortium.org/index.php/olj/article/view/1273

Moore, M. G. (2019). The theory of transactional distance. In M. G. Moore \& W. C. Diehl, (Eds.), Handbook of distance education, (4th ed., pp. 32-46). Routledge. https://doi.org/10.4324/9781315296135

Moore, M. G., \& Kearsley, G. (2012). Distance education: A systems view of online learning (3rd ed.). Wadsworth.

McNeal, L., \& Gray, J. (2019). A new spin on quality: Broadening online course reviews through coaching and slow thinking. Online Journal of Distance Learning Administration, 22(4). https://www.westga.edu/ distance/ojdla/winter224/monealGray224.html

Nilsen, P. (2015). Making sense of implementation theories, models and frameworks. Implementation Science, 10(53). doi 10.1186/s13012-015-0242-0 https://implementationscience.biomedcentral.com/track/pdf/10.1186/s13012-015-0242-0

O'Brien, E. (2015). A case study evaluation of quality standards and online faculty development [Doctoral dissertation, University of Central Florida]. University of Central Florida Library. https://stars.library.ucf.edu/etd/1239

Piña, A. A., \& Harris, P. (2019) Utilizing the AECT instructional design standards for distance learning. Online Journal of Distance Learning Administration, 22(2). https://www.westga.edu/ distance/ojdla/summer222/pina_harris222.html

Quality Matters, (n.d.). Member institutions/organizations. https://www.qmprogram.org/qmresources/subscriptions/subscribers.cfm?program=0

Quality Matters, (n.d.). Quality assurance begins with a set of standards. https://www.qualitymatters.org/qa-resources/rubric-standards

Rhode, J., Richter, S., \& Miller, T. (2017). Designing personalized online teaching professional development through self-assessment. TechTrends, 61(5), 444-451. http://www.aeraotl.com/otl-news 
Richardson, J. W., Hollis, E., Pritchard, M., \& Lingat, J. E. M. (2020). Shifting teaching and learning in online learning spaces: An investigation of a faculty online teaching and learning initiative. Online Learning 24(1), 67-91. https://doi.org/10.24059/olj.v24i1.1629

Ryan, P. (2015). Quality assurance in higher education: A review of literature. Higher Learning Research Communications, 5(4). http://dx.doi.org/10.18870/hlrc.v5i4.257

Sanga, W. M. (2018). Getting to master online teaching: Insights from purposefully organized course development training. Quarterly Review of Distance Education, 19(2), 15-22.

Scarpena, K., Riley, M., \& Keathley, M. (2018). Creating successful professional development activities for online faculty: A reorganized framework. Online Journal of Distance Learning Administration, 21(1). https://www.westga.edu/ distance/ojdla/spring211/scarpen_riley_keathley $211 . \mathrm{html}$

Seaman, J. E., Allen, I. E., \& Seaman, J. (2018). Grade increase: Tracking distance education in the United States. Babson Survey Research Group. https://onlinelearningsurvey.com/reports/gradeincrease.pdf

Shattuck, K. (2019). Teaching online: Where? what? who? when? why? how? In M. G. Moore \& W. C. Diehl (Eds.), Handbook of distance education (4th ed., pp. 428-442). Routledge Press. https://doi.org/10.4324/9781315296135

Shattuck, K., Zimmerman, W., \& Adair, D. (2014). Continuous improvement of the QM Rubric and review processes: Scholarship of integration and application. Internet Learning, 3(1), 25-34. http://joom.ag/w08b/p24

Shearer, R. L., Park, E. (2019). Theory to practice in instructional design. In M. G. Moore \& W. C. Diehl (Eds.), Handbook of distance education (4th ed., pp. 260-280). Routledge Press. https://doi.org/10.4324/9781315296135

Shelton, K. (2010). A quality scorecard for the administration of Online Education programs: A Delphi study (Publication No. 3423965). [Doctoral dissertation, University of Nebraska]. ProQuest Dissertations and Theses Global.

Swan, K., Day, S. L., Bogle, L. R., \& Matthews, D. B. (2014). A collaborative, design-based approach to improving an online program. Internet and Higher Education, (21), 74-81. https://doi.org/10.1016/j.iheduc.2013.10.006

Taylor, C., Roehrich, H., \& Grabanski, J. (2018). External factors that impact online instructor performance: A study measuring the impact of decision fatigue $\&$ quality matters recognition of courses on online instructor evaluation. Online Journal of Distance Learning Administration, 21(3). https://www.westga.edu/ distance/ojdla/fall213/taylor_roehrich_grabanski213.html 